\title{
Some Information Concerning Yom Tob Atias (Jeronimo de Vargas)
}

Herman P. Salomon *

The University at Albany

The team of Ferrara editors was headed by two former New Christians: an entrepreneur, a native of Spain, and a Latin scholar from Portugal who in the introductions to variant editions of their scriptural production alternately call themselves by their Christian names Jeronimo de Vargas and Duarte Pinel, and by their Jewish names Yom Tob Atias and Abraham Usque. This "editorial schizophrenia" is reflected in the Italian archives. Whereas the historian Renata Segre's researches have documented that Duarte Pinel and Abraham Usque were one and the same person, she was unable to find archival proof uniting Jeronimo de Vargas and Yom Tob Atias. The researcher Aron Leoni came up with a Latin notarial deed in the Ferrara archives wherein "Joantu Athias" is called "ptrem ac legitimum administratorum Hieronimi Vargas" and also the latter's "patre et legitimo administrator." He supposed "ptrem" to be an abbreviation of "procuratorem" and "patre" to mean father. Thus he concluded that Yom Tob Atias was the father of Jeronimo de Vargas. Close examination of the document and comparison with two others which have recently come to light reveal, however, the incontrovertible identity of Yom Tob Atias and Jeronimo de Vargas. We are dealing with a typical case of ex-Marrano heteronomy: a former New Christian maintaining a separate onomastic Christian identity alongside his Jewish one.

KeYwords: Hebrew Press; Ferrara; Marranos; Cultural Identities; Onomastics; Heteronomy.

Noticias en torno a Yom Tob Atías, alias Jerónimo de Vargas.- El equipo de editores de Ferrara fue dirigido por dos antiguos cristianos nuevos, uno financiero, originario de España, y el otro, un latinista portugués. En las distintas introducciones a edición bíblica los dos se autodenominan alternativamente por sus nombres cristianos -Jerónimo de Vargas y Duarte Pinel- y por sus nombres judíos, Yom Tob Atías y Abraham Usque. Esta «esquizofrenia editorial» ha dejado huella en los archivos italianos. Mientras que las investigaciones de Renata Segre han documentado que Pinel y Usque eran la misma persona, no consiguió una prueba archivística para identificar a Vargas y Atías. El investigador Aron Leoni descubrió en los archivos de Ferrara un documento notarial en latín, en el que «Juantu Athias» es denominado «ptrem ac legitimum administratorum Hieronimi Vargas» y también «patre et legitimo administrador» de este último. Leoni conjeturaba que «patrem» era una abreviatura de «procuratorem» y que «patre» significaba

\footnotetext{
*herman_prins_salomon@hotmail.com
} 
padre, concluyendo que Atías sería padre de Jerónimo de Vargas. Un reexamen del documento y su comparación con otros dos que han salido a la luz revelan que Yom Tob Atías y Jerónimo de Vargas eran la misma persona: estamos en presencia de un caso típico de identidad doble entre antiguos cristianos nuevos que habían adoptado el judaísmo fuera de la península Ibérica, manteniendo su identidad onomástica cristiana, pero separada de la judía.

PALABRAS CLAVE: imprenta hebrea; Ferrara; conversos; identidad cultural; onomástica; heterónimo.

In 1552 there appeared in Ferrara (Italy):

Lybro / de Oracyones / de todo el año traduzido del / Hebrayco de verbo a ver- / bo de antiguos exem- / plares: por quanto / los ympressos / fasta a qui / estan errados: con muchas / cosas acrescentadas de / nueuo segun por la / siguiente tabla se muestra. / 5312 De la Criacion / a 14 de Siuan / Ympresso por yndustria y despesa / de Yom Tob Atias hijo / de Leui Atias.

The reference to "those printed until now" is to Hebrew prayer books printed at Venice. ${ }^{1}$ This is the first Spanish translation of the entire prayer book ever published and is the ultimate ancestor and source of all Spanish translations of Sephardic prayers printed and reprinted time and again in the Northern Netherlands $1584-1772 .^{2}$

I know of six surviving copies: Biblioteca Nacional de España; British Library; Hebrew Union College, Cincinnati; Ets Haim/Livraria Montezinos; Bibliotheca Rosenthaliana; my own. In 1995 Moshe Lazar published a critical edition. ${ }^{3}$ On the title-page of my copy the words "Ympresso [...] Atias" are lacking.

In 1553 there appeared in Ferrara:

BIBLIA / En lengua Española traduzida palabra / por palabra dela verdad Hebrayca / por muy excelentes letrados vista y examinada por el officio / dela Inquisicion / Con priuillegio del yllustrissimo Señor / Duque de Ferrara.

This is the earliest printed Spanish translation of the complete Jewish Scriptures (Old Testament). In 1992 Moshe Lazar (who published a critical edition that

${ }^{1}$ See H. P. Salomon, "Was there a Traditional Spanish Translation of Sephardi Prayers Before 1552?," The American Sephardi 6, 1-2 (1973), pp. 78-92.

${ }^{2}$ See A. K. OfFenberg, "Exame das tradições. Een bibliografisch ondersoek naar de publikaties der eerste Sefardim in de Noordelijke Nederlanden (1584-1627)," in Exxodo, Portugezen in Amsterdam, 16001680 (Amsterdam 1987), pp. 56-69.

${ }^{3}$ Libro de Oracyones Ferrara Ladino Siddur (1552) (Lancaster, Ca. 1995). Five surviving copies of the original are listed on p. xxiii. 
year) knew of 61 surviving copies. ${ }^{4}$ That same year a facsimile edition appeared in Madrid, with a separate volume of introductions and notes and an appendix.

A part of the issue of the Bible comprises a dedication to the Duke of Ferrara, signed:

Jeronimo de Uargas y Duarte Pinel.

The other part of the issue comprises a prologo a la muy magnifica Señora Doña Gracia Naci ${ }^{6}$, signed:

Yom Tob Atias y Abraham Usque

The copies dedicated to the Duke have the following colophon:

A gloria y loor de nuestro Señor se acabo la presente Biblia é lengua Espa-/ ñola traduzida dela verdadera origen Hebrayca por muy excelentes / letrados: con yndustria y deligencia de Duarte Pinel Por-/ tugues: estampada en Ferrara a costa y despesa de / Jeronimo de Uargas/ Español: en primero de Março / de 1553.

The copies addressed to Gracia Naci have the following colophon:

A gloria y loor de nuestro Señor se acabo la presente Biblia é lengua Espa-/ ñola traduzida dela verdadera origen Hebrayca por muy excelentes / letrados: con yndustria y deligencia de Abrahã Usque Por-/ tugues: estampada en Ferrara a costa y despesa de / Yom Tob Atias hijo de Levi Atias/ Español: en .14. de Adar / de. 5313.

The first four lines of the two texts are typographically identical. Consequently, it is abundantly clear that in the mind of the compositor Duarte Pinel, Portuguese and Jeronimo de Vargas, Spaniard, are the same as Abraham Usque, Portuguese ${ }^{7}$ and Yom Tob Atias, Spaniard. That Duarte Pinel / Abraham Usque is in fact one and the same person was definitively established by the historian Renata Segre, on the basis of a Latin document kept in the Archivio Storico Communale di Fer-

${ }^{4}$ The Ladino Bible of Ferrara [1553] (Culver City, Ca. 1992). See his list of surviving copies, xxiv-xxvii.

${ }^{5}$ La Biblia de Ferrara (1553).

${ }^{6}$ See H. P. SAlomon and A. di Leone Leoni, "Mendes, Benveniste, de Luna, Micas, Nasci: The State of the Art (1532-1558),"JQR 88 (1998), pp. 135-211; and 89 (1999), pp. 389-391.

\footnotetext{
${ }^{7} \mathrm{He}$ was also the printer of a Latin grammar (Lisbon 1543, under the name Eduardus Pinellus) and of 30 books at Ferrara under the name Abraham Usque, 1553-1557, mostly in Hebrew, some in Spanish, two in Portuguese, namely Consolaçam às Tribulacoens de Israel (Ferrara 1553) and Menina e Moça (Ferrara 1554). See H. P. SAlomon, "O que tem de judaico a Menina e Moça?" Cadernos de Estudos Sefarditas 4 (2004), pp. 185-223.
} 
rara, dated January 19, 1554, wherein reference is made to Abramus Usque vulgo cognominatus Odoardus Pinellus lusitanus. ${ }^{8}$ She was unable, however, to find a parallel document uniting Jeronimo de Vargas and Yom Tob Atias.

The learned researcher Aron di Leone Leoni found in the Ferrara archives a notarial deed (Archivio di Stato di Ferrara, notaio Nicola Caprilli, Matr. 504, Pacco 2, November 2, 1556) wherein mention is made by Joantu Athias Lusitanum, ptrem ac legitimum administratorem dicti Hieronimi Vargas of printing presses rented by Jeronimo Vargas from G. M. Niccolini, kept in storage by one Jacob Abravanel. A couple of lines further down, the same Joantu is called patre et legitimo administratore of Jeronimo de Vargas. Leoni correctly assumed "ptrem" to be an abbreviation of procuratorem ("procurator') but (mistakenly, I think) supposed "patre" to mean "father." "

The forms "ptrem" and "patre" are here both evidently abbreviations of procuratore $(m)$. Athias Lusitanus is designated the authorized representative of Jeronimo de Vargas, but obviously not his father, for if he were his father that would have been indicated right at the beginning of the document.

There is no reason to hypothesize "Iantu Athias Lusitanus" to be a different person from "Yom Tob Atias español." The notarial deeds of Ferrara hardly distinguish between Spaniards and Portuguese, which is not surprising when we consider the fact that all the Sephardic immigrants to Ferrara hailed from Portugal, regardless whether they were the Spanish exiles of 1492, the latter's Portuguese-born descendants or the descendants of Jews resident in Portugal prior to 1492. Such subtle distinctions between "Spaniards" and "Portuguese" were maintained more among themselves than by their Italian hosts. ${ }^{10}$

The equivalence between the surnames Vargas and Atias is apparent from a document consulted by Aron di Leone Leoni in the Archivio di Stato di Ancona (not. G.B. Agli, reg. 205, December 3, 1550): Salomon Atias declares that when he resided at Antwerp he had gone by the name Pedro de Vargas. (Renata Segre later identified him as Jeronimo's brother. ${ }^{11}$ ) Thus, in the Ferrara document dated November 2, 1556, we are dealing with two persons who bear the

\footnotetext{
${ }^{8}$ See R. SEgRe, "La Tipografia ebraica a Ferrara e la stampa della 'Biblia' (1551-1559)," Italia Medioevale e Umanistica 35 (1992), pp. 305-332:322 (Spanish translation: "Contribución documental a la historia de la Imprenta Usque y de su Edición de la Biblia," in Introducción a la Biblia de Ferrara. Actas del Simposio Internacional sobre la Biblia de Ferrara, ed. I. M. Hassán, Madrid 1994).

9 "New Information on Yom Tob Atias (alias Alvaro Vargas), Co-publisher of the Ferrara Bible," Sef 57 (1997), pp. 271-276.

${ }^{10}$ See SEgre, "La Tipografia ebraica a Ferrara,” p. 318. Leoni, "New Information,” p. 274 , n. 19 cites proceedings in the Arquivo de Modena which refers to Hieronimo Vargas Hispani in the title and describes him as Lusitanus in the body of the same document.

${ }^{11}$ SEgRe, "La Tipografia ebraica a Ferrara," p. 319.
} 
names de Vargas / Atias, neither one present in the notary's office. One of them is dissimulating the name Atias and the other the name de Vargas. It appears to me that these two persons, to wit Jeronimo de Vargas and his authorized representative Iantu Atias Lusitanus, are one and the same. But let us not anticipate.

Segre found in the Ferrara Archives a Latin deed dated a half year later (Archivio di Stato di Ferrara, notaio Giacomo Conti, Matr. 584, Pacco 7, May 12, 1557), wherein reference is made to magister Alvarus, uti pater [pator?] et legitimus administrator Hieronimi de Vargas eius filii [...] ac patrem et uti proc et legitimum administratorem. ${ }^{12}$ Twice more we see here the formula "procurator et legitimus administrator." The word "procurator" is abbreviated alternately "pater" (or "pator"?) and "proc." The scribe, who is merely copying out, will have failed to discern and so to make the distinction between the words "patre(m)" (father) and the divers abbreviations of "procuratore(m)" (authorized representative). This particular document, for instance, is found twice in the ledger, presenting small variants and a different division of lines.

Magister Alvarus (whose last name is not divulged in the document but may easily be guessed) is presented as the father of Duarte de Vargas, deceased at Seville, and of Jeronimo de Vargas, absent from Ferrara. He is the grandfather of Alvaro, Manuel and Jeronimo, sons of his son Duarte. Thus in the first document we have Iantu (= Yom Tob) Atias, authorized representative (but not the father) of Jeronimo de Vargas and, in the second document, Alvaro de Vargas, father and authorized representative of Jeronimo de Vargas.

Let us for a moment return to the title-page of the 1552 Libro de Oracyones and to the colophon (second version) of the 1553 Ferrara Bible, where we meet the name of Levi Atias, father of Yom Tob Atias. Segre explains that among the Sefardim of Italy "Alvaro" is regularly found as the Christian equivalent of "Levi," no doubt thanks to the occurrence of the consonants LV in both names. ${ }^{13}$ In the same way the equivalence between Jeronimo and Iantu (Yom Tob) may be explained by the coincidental initial. Master Alvaro is in turn the son of a deceased Jeronimo. ${ }^{14}$ It is therefore obvious that Master Alvaro de Vargas is the same as Levi Atias, namely the father of Yom Tob Atias, alias Jeronimo de Vargas. Yom Tob Atias cannot be his own father and is therefore not the father of Jeronimo de Vargas.

Indeed, Renata Segre discovered at Pesaro a decisive Latin document (Archivio di Stato di Pesaro, notaio Francesco Fattori, vol. 9, ff. 84r-85r) that settles

\footnotetext{
${ }^{12}$ Cited by Segre, “Contribución documental,” p. 221, n. 41; "La Tipografia ebraica a Ferrara,” p. 325, n. 42.

${ }^{13}$ Segre, "La Tipografia ebraica a Ferrara," p. 318, n. 2. Leoni accepts this equivalence ("New Information,” p. 273, n. 12).

${ }^{14}$ SEgRe, "La Tipografia ebraica a Ferrara,” p. 325, n. 42, document dated August 24, 1550.
} 
the matter. On December 16, 1557, at Pesaro, Hieronymus de Vargas, hebreus Portughensis in presentarium moram trahens in Civitate pisauri, charges a Ferrara solicitor as well as leyvas athiam hebreum eius prem with a new lawsuit against the printer G. M. Niccolini. ${ }^{15}$ In this document the word "procuratores" occurs twice, fully spelled out. Therefore "eius prem" = "eius patrem" (his father, Levi Atias = Alvaro de Vargas).

Having shown that Yom Tob Atias (alias Jeronimo de Vargas) cannot be his own father, we are still faced by the problem of how he can be his own authorized representative.

It seems to me that we have here a typical case of ex-Marrano heteronomy (duplicity?): a former New Christian who maintains a Christian identity alongside his Jewish one in order to protect family members in the Peninsula (and eventually himself) from Inquisitorial molestation. Until now not a single Ferrara notarial document has come to light from which emerges the incontrovertible identity of Yom Tob Atias and Jeronimo de Vargas. Only one time, in the Pesaro document dated December 16, 1557, Jeronimo de Vargas is designated an "hebreus" and, moreover, the son of Levi(as) Atias. In his relations with the ducal authorities of Ferrara he identifies himself consistently as a "mercator lusitanus" and never as a Jew. Renata Segre calls attention to the fact that of his four children, living in Ferrara, we only know the Christian names (Alvaro, Marco, Francisco, Catarina), divulged in the last will of their grandfather who raised them, to which is affixed an affidavit signed by the Protonotarius Apostolic. ${ }^{16}$ I should also like to point out once more that -in contrast with the Ets Haim /Livraria Montezinos copy- the title-page of my Libro de Oracyones omits Atias' name. Thus we are dealing with one person's two separate identities, namely Yom Tob (or Yantu) Atias "hebreus ferrariensis" (as well as Spaniard) and Jeronimo de Vargas "mercator lusitanus" (as well as Spaniard). On May 12, 1557, at the notarial office in Ferrara of Nicolo Caprilli, Yoantu Athias (alias Jeronimo de Vargas) is presented as the "legitimate (!) administrator" of Jeronimo de Vargas (alias Yom Tob Atias). No one saw through the little game. ${ }^{17}$

\footnotetext{
${ }^{15}$ See Archivio di Stato di Pesaro, notaio Francesco Fattori, vol. 9, ff. 84r-85r. Cf. SEgre, "La Tipografia ebraica a Ferrara," p. 319, n. 27 (correct "December 10" into December 16); Leoni, "New Information," p. 275, n. 24 (correct "December 9" into December 16).

${ }^{16}$ SegRe, "La Tipografia ebraica a Ferrara," p. 324, n. 40, document dated October 11, 1554.

${ }^{17}$ I thank Dott. Antonietta Folchi, curator of the Archivio di Stato di Ferrara and Dott. Graziella Berreta, curator of the Archivio di Stato di Pesaro for scans of the three Latin notarial documents cited in the text; Dott. Aron di Leone Leoni, Prof. John Monfasani and Dr. Carsten Wilke for their help with the complete transcription of the two Ferrara ones; Prof. Raul Miguel Rosado Fernandes for his line-by-line translation of the same; Dr. Adri Offenberg: Prof António Feijó, Dr. Adri Offenberg and Dr. Carsten Wilke for divers suggestions; Prof. John Monfasani for his luminous idea.
} 


\section{Appendix I}

Archivio di Stato di Ferrara [= ASFe], notary Nicola Caprilli, Matr. 504, Pacco 2, 2 November, 1556.

Depositum et promissio pro magistro Ioanne Maria Niccolino a M.co D. Iacob Abravanello,

Conservatio indemnitatis predicti Domini Iacobi a Ioantu Athias

1556 Indictione XIIII

${ }_{2}$ Die 2 Novembris Ferrariae in curtili novo ducali presentibus ${ }_{3}$ domino Petro Antonio Bellaia alias de Morelettis et domino ${ }_{4}$ Thoma Mazzarello et aliis.

${ }_{5}$ Magnificus dominus Iacob quondam domini Samuellis de Abravanellis ${ }_{6} \mathrm{He}-$ braeus Ferrariae morans, sponte obligando se ${ }_{7}$ ad instantiam mei notarii infradicti publicae personae, presentis ${ }_{8}$ stipulantis nominibus et vice omnium et singulorum ${ }_{9}$ quorum interest intererit, dixit, ei confessus fuit / ${ }_{10}$ habuisse et recipisse ac habere penes se realiter et ${ }_{11}$ cum effectu in depositum duo torcularia pro stam- ${ }_{12}$ pando, seu imprimendo, cum omnibus bonis quae ${ }_{13}$ locata fuerunt per Ioannem Mariam Nicolinum ${ }_{14}$ Hieronimo de Vargas, exceptis tamen iis bonis quae ${ }_{15}$ sibi Hieronimo fuerunt evicta in iudicio per Leonardum ${ }_{16}$ de Brixia, et quae torcularia et bona penes se ${ }_{17}$ dixit deposuisse Ioantu Athias Lusitanum, ptrem [= procuratorem] ${ }_{18}$ ac legitimum administratorem dicti Hieronimi Vargas, ${ }_{19}$ et quae torcularia et bona, una cum omnibus affictibus ${ }_{20}$ debitis et debendis dicto Ioanni Mariae, ipse dominus ${ }_{21}$ Iacob ut supra obligando (sciens non teneri ad dictos affictus, sed volens teneri motus precibus et instantia dicti Ioanni Actias) promisit restituire [et] asolvere predicto Ioanni ${ }_{22}$ Mariae vel cui de iure restituenda venieret omni vece et // ${ }_{23}$ quandocunque dictus Ioannes Maria, computum fecerit ${ }_{24}$ cum dicto Hieronimo de Vargas vel cum dicto Ioamtu ${ }_{25}$ eius patre [= procuratore] et legitimo administratore et restitutionem ${ }_{26}$ veram et realem faceret ${ }_{27}$ et renuntiaverunt ${ }_{28}$ quae omnia ${ }_{29}$ sub poena librarum XXv milliarium

${ }_{30}$ Ego Nicolaus a Caprili notarius rogatus ${ }_{31}$ et illico presentibus testibus superdictis ${ }_{32}$ Iuanto Athias predictus sponte obligando promisit predicto domino ${ }_{33}$ Iacobo Abravanello presenti ipsum dominum Iacob et ${ }_{34}$ suis heredes et bona indemnem, indemnes et indemnia ${ }_{35}$ ac sine damno penitus conservare a fideiussione et obliga${ }_{36}$ tione supra per eum facta et rogata per me notarium infradictum, ${ }_{37}$ in omnibus et per omnia. 


\section{Appendix II}

ASFe, notary Giacomo Conti, Matr. 584, Pacco 7, 12 May, 1557

${ }_{1}$ Mandatum Magistri Alvari portugalensis in Emanuelum Lopes

${ }_{2}$ Eisdem millesimo et indictione, die 12 mensis maii, Ferrarie in domo habitationis infrascripti magistri Alvari portugalensis sita in contrata Sancti Romani, presentibus ${ }_{4}$ testibus [...]

${ }_{7}$ Magister Alvaris portugalensis vicinus Portalegre, Ferrarie de presente mo- ${ }_{8}$ rans in dicta contrata Sancti Romani, agens tamquam tutor et curator tes- ${ }_{9}$ tamentarius personarum et bonorum Alvaris et Emanoelis et Hieronimi fratrum ${ }_{10}$ filiorum et heredum olim Odoardi de Vargas olim filii ipsius magistri Alvari.

${ }_{11}$ Decretus datus per dictum quondam Odoardum de Vargas dictis suis filiis in ${ }_{12} \mathrm{ul}$ timo testamento dicti quondam domini Oduardi de Vargas condito in civitate Siviglie ${ }_{13}$ regni Castilie sub die 26 octobris anni preterito 1554 nec non ${ }_{14}$ agens ipse magister Alvarus uti pater $^{18}$ [= procurator $]$ et legitimus administrator Hieronimi ${ }_{15}$ de Vargas eius filii de presentis absentis a civitate Ferrarie et omni alio meliori ${ }_{16}$ et via cum eo magistro Alvaro honoranda mulier Domina Isabella de ${ }_{17}$ Sanchies portugalçensis vidua relicta quondam dicti Odoardi de Vargas ${ }_{18}$ defuncti suo proprio et principali nomine et per omnes et quocunque suo interesse in omni ${ }_{19}$ alio quounque meliori modo, non revocantes [alios procuratores] fecerunt contituerunt ${ }_{20}$ eorum procuratores Emanuelem Lopes mercatorem in Viglia Viciosa ${ }_{21}$ in regno Portugaliae, Alphonsum Vas et Simonem Pires mercatores ${ }_{22}$ Lisbone, omnes portugalenses, licet absentes et quemlibet eorum in solidum ${ }_{23}$ specialiter et expresse ad ipsorum constituentium nomine petendum exigendum // ${ }_{24}$ debitas seu spectantes et pertinentes ipsis Alvaro, Emanueli ${ }_{25}$ et Hieronimo, filiis et heredibus dicti Odoardi de Vargas seu ipsi dicte ${ }_{26}$ Isabelle Sanchies et seu dicto Hieronimo de Vargas quomodocumque $[\ldots]_{27}$ literis et ex a quacumque ratione vel causa et precipue a Didaco ${ }_{28}$ Guaimes mercatore morante Lisbone, mille centum octua ${ }_{29}$ gintaquatuor crusatos auri quos dietus debitos per dictum Didacum ${ }_{30}$ Guaimes dicto quondam Odoardo de Vargas


litteras cambii directivas ${ }_{33}$ Ioanni Fernandes de Alvito solvendas dicto Didaco Guimes

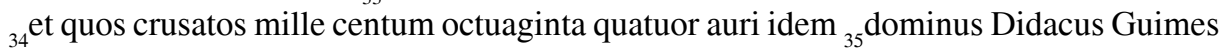
recepit et recuperavit a predicto Ioanni Fer- ${ }_{36}$ nandes de Alvito in dicta civitate Lisbone de pecuniis ipsius ${ }_{37}$ olim Odoardi de Vargas sibi Didaco Guaimes remissis [...]

${ }_{40}[\ldots]$ faciendum finem confessionem, absolutionem $[\ldots]$

${ }_{42}[\ldots]$ et in ${ }_{43}$ predictis omnibus obligandum ipsum constituentem et tutorem et curatorem antedictum ${ }_{44}$ ac patrem et uti proc [= procuratorem $]$ et legitimum administratorem antedictum $_{45}$ ac et ipsam dominam Isabellam Sanchies [...]

\footnotetext{
${ }^{18}$ Perhaps "pator."
} 
Appendix III

Family ATIAS / DE VARGAS

a.k.a. $=$ also known as

$\mathrm{m} .=$ married

\author{
Jerónimo DE VARGAS \\ Mestre Álvaro DE VARGAS \\ a.k.a. Levi (Levias) ATIAS \\ children
}

Jerónimo DE VARGAS

Pedro DE VARGAS Duarte DE VARGAS

a.k.a. Yom Tob (Joanto) ATIAS

a.k.a. Salomon ATIAS (died in Seville)

m. to Isabel Sanches

m. to Leonora Avendina

children:

Álvaro Manuel Jerónimo

children:

Álvaro Marco Francisco Catarina

Recibido: 16/09/2009

Aceptado: 21/11/2009 